\title{
Syrian Civil War: A Historical Study from the Russian Perspectives
}

\author{
Md. Shafiqur Rahaman \\ Lecturer, Department of History and Bangladesh Studies, Pabna University of Science and \\ Technology
}

\begin{abstract}
The study is about Russian perspectives on Syrian civil war. In this paper, I have explained that why and how Russia launched an air campaign in Syrian civil war and what is the prime motto of the Rush air strike in Syria. For Russia, Syria is another one which is not comparable with other Russian allies. Historically, they are the intimate allies and now Russia is the only remaining super power who is giving military and economic support for the al-Assad government. From the Russian point of view, it is assisting for the Syria and will assist until a better solution for the president al-Assad government. By doing this Vladimir Putin wants to establish Russian respect internationally.
\end{abstract}

Keywords: Syria, Russia, Middle East,Airstrike, ISIS

\section{INTRODUCTION}

In the world, the politics of the Middle East is the politics of tough and rough where super powers want to play a great game. Syria is one of the countries where Russia interest. After the cold war, especially under Vladimir Putin leadership Russian foreign policy became more assertive and adaptable. Following the 'multivector' foreign policy, Putin is trying to build up good alliances with old and most influential countries in the world. Therefore, from the beginning of the Syrian civil war Rush foreign policy in Syria has appeared. On 30 September 2015, Russia started an air campaign against opponents of the President Bashar al-Assad. From the inception of the air strike in Syria, the western block, and the western-based humanitarian institutions claimed civilians were killed by Rush bombing and many people became homeless which createda humanitarian crisis. But the Russian president Vladimir Putin stated, our troops are targeting the terrorists, in Syria, our forces are combating against ISIS. On the contrary, I will discuss Russian perspectives from historical study in Syrian civil war which has been ignored by the many scholars of the contemporary international history.

\section{RESEARCH METHODOLOGY}

To write this article I have used the historical method and have used content analysis method. For the primary sources, I have used several sources for the interview with the president and the prime minister of the Russia and Syria and leading Russian government and pro-government newspaper such as Tass, Pravda, The Moscow times and the sputnik times. Secondary sources have been collected from various scholarly journals and books on Russia, Syria, Middle East and the world politics.

\section{BACKGROUND}

In recent time Syrian civil war becomes a burning issue in international politics. Not only it is dominating the international politics, but also spreading the most alarming news about ISIS, the most dangerous terrorist group in the contemporary world. The Russian government has already engaged in this war and closely observing on the war. But why the Russian government has a great headache in this war. To get this answer we have to get back to see in Soviet-Russian past history. Russian Prime Minister Dmitry Medvedev also said, "Russia does not support President al-Assad personally, but maintains friendly relations with Syria as a country. These ties built not under Bashar al-Assad, but back when his father, Hafez al-Assad, was President." So Soviet past history can give us an overview about Russia-Syria friendship. Prior to Rush revolution of 1917,Tsar Nicholas II was the 
emperor of all Russia. During the concluding period of Nicholas II that means in the rearmost period of the First World War Russia were facing a lot of trouble, including millions of Russian troops slaughtering in the war, falling administration, millions of people starving and freezing, economic and political chaos and peoples were demanding bread to save their life. ${ }^{2}$ But Tsar was unable to take any proper decision to save Russia. Historian said, this unbalanced situation ran Russia for the certain revolution and the opportunist seeker Bolsheviks had taken this gingerly. Finally on 24 October 1917 Rush revolution was occurred by the proper and adept planned of Lenin. After the revolution, the history of modern Russia had changed dramatically and the world experienced the socialist state for the first time. On 30 December 1922, Union of the Soviet Socialist Republics (USSR) was established by the Treaty on the Creation of the USSR. ${ }^{3}$ From the very beginning of the USSR, the country had to struggle to search new comrade. Because it was an ideological war between the capitalist and the socialist and after the Second World War it was all over limpid to all. During the cold war, the USSR and the USA emerged as the competitive world powers and both of them were trying to establish new comrade of which countries were strategically very important in world politics. Following the way the Middle East, was a dynamic and vital sources of oil and strategic world politics. Geopolitically Syria has a great significance from the Arab side, and also from the Israel side. ${ }^{4}$ On the other hand, "Syria has also historically been a natural partner repeatedly sought by states such as Egypt, Iraq and Saudi Arabia to balance rival power constellations. This geopolitical centrality gave Syria an importance which could be parlayed into resources and diplomatic support beyond its own borders." 5 It is well known that, if anyone wants to establish a peaceful environment in the Middle East he or she will need Syria's cooperation. In this way Henry Kissinger once said, "There can be no war in the Middle East without Egypt and no peace without Syria." ${ }^{\circ}$ So in the struggle for existence, Soviet Union considered Syria as one of the most important allies in the Arab World. In the era of Nikita Khrushchev (1953-1964), the USSR provided Syria more than \$ 200 million military aid to avert U.S. and her foremost ally Israel influences in the Arab World. ${ }^{7}$ During the Arab-Israel war of 1967, Leonid Brezhnev sided with Syria and encouraged his Arab allies against U.S.-Israeli aggressions in Arab arena. He stated that "we have helped and we are continuing to help the Arab states" ${ }^{8}$ According to Dr. Michael Sharn off, after the war, the USSR provided Syria \$ 2.5 billion military aid from July1967 to December 1968 to establish strong military capacity against Israel. ${ }^{9}$ In 1971 Hafez alAssad became the president of Syria by a coup. Hafez al-Assad established a strong relation with the USSR. In February 1972 the USSR and the Syria signed in peace and security treaty which strengthened Syria's military capability. Under the Brezhnev government, Syria was one of the largest recipient's Arab countries who brought or received $\$ 19.1$ million value of arms. ${ }^{10}$

In the era of Gorbachev, The USSR-Syria relation became flexible. ${ }^{11}$ Following the Perestroika policy, Gorbachev didn't interest to give huge military aid for the third world country. ${ }^{12} \mathrm{He}$ remarked the aid as an 'unproductive-military' project. ${ }^{13}$ But Syria was another case. It was very complex to measure. Scholarly said for the geostrategic significance Gorbachev approved several arms (Mig29s, tanks, and air defense systems, etc.) and military advisors for the Syrian government. ${ }^{14}$ After the dissolution of the USSR, The USSR-Syria relation didn't disintegrate but developed time to time. On 24 January 2005, Syrian President Bashar al-Assad visited Moscow and deliberated with President Vladimir Putin. President Putin explained his meeting with President Assad as "an important milestone in our bilateral relations." ${ }^{15}$ Meeting of Vladimir Putin with al-Assad Russia-Syria relation became new dimension for twenty-first century. This dimension provided Syria to get a strong support like mutual cooperation, arms, aid, and technology and so on from Russia. That has been already proved.

\section{SYRIAN CIVIL WAR AND RUSSIAN PERSPECTIVES}

In Syria, The long despotic ruling system instituted a playground of civil war and the Arab spring provided the sparks in this institution. In this way, the bloody Syrian civil war was started on 15 March 2011. From the inception of the war, the Russia has been pleading for the Syrian government diplomatically, economically and militarily. Still now Russia is a last remaining strong ally of the Syria. On 4 September 2015, the Russian President Vladimir Putin clearly answered to the Russian journalist's question about Russia-Syria ties. He stated that,

"We signed major contracts with Syria some 5-7 years ago, and we are complying with them in full. Therefore, we are considering various scenarios, but so far, what you have mentioned is not on our agenda. However, we will continue our consultations both with our friends in Syria and with the 
countries in the region." ${ }^{16}$ Putin's statement was a message for the air strike tilt in favor of Bashar alAssad. Finally, on 30 September 2015, Russia had begun airstrike against the opposition groups of Bashar al-Assad in Syria. After the beginning of the air strike in Syria, Russia had to face western criticism. The Prime Minister Dmitry Medvedev had spoken against the western critic with Euro news TV channel interviewed. He said, "there is a legal foundation in the form of the request by President al-Assad. ${ }^{, 17}$ During the air strike,(30September 2015- present) The Syrian government gained several ISIS and FSA (free Syrian army) controlled most strategic towns and killed more than two thousand IS members and leaders that were claimed by Russia. On the other hand, humanitarian organizations and peacekeeper people have accused Russia of killing and casualties, thousands of civilians and creating refugees in Syria. It is absolutely true that the Russian air strikes were enfeebled both IS and FSA's members, but unable to nip in the bud of these groups. Still now the civil war is running. No one can determinately say what will be done after two or three months.

Observing several government and non-government Russian sources, it is clear to us that Russia is examining Syrian civil war from three major perspectives; war against ISIS, protect legitimate government and holding Syria strategically.

\subsection{War Against Terrorism}

In contemporary world, the war against terrorism is a most recognized concept to all people of the world. Basically, after the terrorist attacked of 9/11, terrorism had been influenced the political, social, economic, cultural and religious life of the world sharply. For Houssoin, 'terrorism is an imprecise word which can cover a multitude of signs and motives but it is now the word which inevitably comes to mind since September $2001,{ }^{18}$ But Russia is another one to combat terrorism. Historians said the north Caucasus war had made a difference between the countries and Russia. That's why; the war against Muslim terrorism is not the new issue for the Russia because Russia has a long background war against Muslim separatist. Historically Russia invaded Caucasus region time to time (1817-1864) including Chechnya, Dagestan, Circassians (Adyghe, Kabarday), Abkhaz, Abazins and Ubykh. In Russia, Caucasus region is more important to Russia for her strategic geographical location. Geographically Caucasus is the point where Russia, Iran, and the turkey connected correlatively and it also situated between the Black and the Caspian seas. ${ }^{19}$ On the other hand north Caucasus is playing a crucial and significant role not only in Russian politics, but also in International politics for her geopolitics and Muslim insurgency. Most of the people of that area belong Sunni Islam. From the beginning of the Russian period, these Muslim majority had refused Rush rule in the north Caucasus. They claimed Russia had occupied our arena by force. Scholarly said that was the reason for the growing of the Muslim insurgency. Aftermath the dissolution of the Soviet Union, the new Russian state was facing an extreme level of socioeconomic and political problems for the lacking of the rule of law. In the prevailing circumstances, the North Caucasus region became restive. ${ }^{20}$ During this turbulent situation, the North Caucasus nationalist movement was raising radically. Particularly the Rush government was altercating the resistance of the Chechen freedom movement. Chechen freedom fighters wanted to take the opportunity of this turmoil situation. They wanted to set themselves free from Russian autocratic rule in Chechnya. Historically, Rush-Chechen conflict was started from eighteen century. From the beginning of the Rush invasion in Chechnya, the several Muslim leaders (Imams) of Chechnya refused Rush imperialism and they united their people to protect Rush invasion. The protecting practice was against Rush imperialism became stronger when Russian empire had occupied North Caucasus region. But the Russian government also wanted to control their strictly and the Rush government had no respect to the full freedom of Chechen people. In this way, the inimical sparks between the rush government and the Chechen people were rising day by day. After the dissolution of the Soviet Union, the freedom movement of the Chechen became totally intractable. As a result, in the history of the North Caucasus region, two bloody and brutal wars (first and second Chechen war) were held in most of the part of the North Caucasus. ${ }^{21}$ It is true that after second Chechen war Rush government had gained victory in Chechnya and established the pro-Russian government in Chechnya. But the unofficially conflict between Russia and the Caucasus Muslim fighters is not over. In recent days it is continuing. The alarming news for the Russian government is uncontrollable jihadists' movements in the North Caucasus region. 


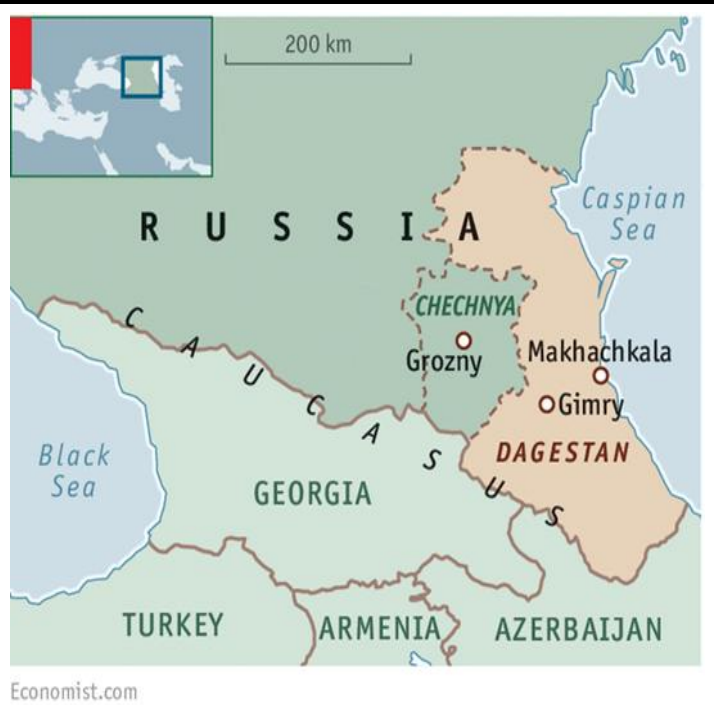

http://www.economist.com/news/europe/21656731-islamic-state-recruiting-volunteers-caucasus-russia-may-beletting-them-go-caucasian

In North Caucasus (Chechen, Dagestan, Ingushetia, and Kabardino-Balkaria) more than $75 \%$ people believe in Islam. Despite belonging Sunni Islam, they also belong Salafism and Wahhabism which is the ultra-radical ideology of Islam. Prior to almost 1000 years ago, salafism was created by some controversial Muslim scholars such as Ibn Taymiayya, Ibn al- Qayyim, Al-Dhahabi, IbnAbd alWahhabNajdi, BinBaz, Uthaymin and Albani. Most of the Muslim leaders and their followers of the North Caucasus region bring up Salafi ideology. In the name of the Islam, they united Muslim people in that arena to inspire jihadist movement against the Russian government. They are the awful fighters and they don't get fear to die. Their ultimate goal was to establish an Islamic state in the North Caucasus region. On the other hand, during the second Chechen war, the insurgency of the Caucasus Emirate created a great headache of the Russian government. But the stringent anti-terrorism policy of the Rush authority emirate's activities became flabby. Ideologically and politically they have a similarity with IS and Al- Qaeda that is the alarming message of the Russian authority. In recent days some scholarly researchers have proved their link. The Russian authority also has consented Russian mujahidin's, especially North Caucasus mujahidin's have a good link with IS. ${ }^{22}$ The Russian government position about terrorism is very clear. Russia does not want to wrangle for another Beslan tragedy at any cost. In an interview with Time Magazine Rush Prime Minister Dmitry Medvedev explained, “... we must prevent extremists and terrorists from getting to Russia from Syria. This is obvious. ${ }^{, 23}$ From the Russian view, the inception military campaign on 30 September 2015 in Syria is the protection of national interest that means protecting Russia from national and overseas terrorist attack. ${ }^{24}$ Dmitry Medvedev estimated thousands of militants from Russian and Central Asia are fighting in Syria. ${ }^{25}$ Last year Vladimir Putin said, “...up to 7,000 people from Russia and former soviet states were fighting in the Middle East for the Islamic State, a terrorist organization banned in Russia. Many of them come from the North Caucasus, where a low-level Islamist insurgency has simmered since the 1990s." ${ }^{26}$ Another source from Dmitry Medvedev, an interview with Handelsblatt (the leading financial daily of Germany, founded in 1946) he said, these militants will come back to Russia with comprehensively brainwashed murders and they want to do that they did in the North Caucasus, Moscow and other Russian cities. ${ }^{27}$ Dmitry Medvedev's speech has been proved by Andrei Przhezdomsky, an advisor to the chair of Russian's national Anti-Terrorism Committee, on an occasion in TASS (Rush garment news agency) he stated to the journalists, 'law and enforcement had caught 832 Russian militants, including 22 recruiters, returning from oversea, and had stopped more than 100 citizens from leaving the country to fight for the Islamic State in Iraq and Syria.",28 Basically, by joining the military campaign with Syria, Russia is trying to protect his national interest that has been uttered again and again by the prime minister of Russia Dmitry Medvedev. On the other hand, the ISIS has a satisfactory interest to control North Caucasus mountain region. On June 23, 2015 ISIS spokesperson Abu Muhammad al-Adnaniannunciated the creation of a new governorate, called wilayatqawqaz (Caucasus) in the Russian north Caucasus arena. ${ }^{29} \mathrm{In}$ a similar way, on $21 \mathrm{June}$ 2015 an audio statement on Twitter, partisans of the ISIS in the Dagestan, Chechnya, Ingushetia and KBK (Kabarda, Balkaria and Krachay) promised strongly to build up a good alliance with ISIS leader Abu Bakar al-Bagdadi. ${ }^{30}$ 


\subsection{Protect Legitimate Government}

It is Russian perspectives, Bashar al-Assad is a legal government still now who was elected in the presidential by the Syrian majority people's votes. Statistics from the first presidential election to last election of Assad regime, he got highest votes from the Syrian people, though the western countries claimed that all elections were unfair. But Russia did not examine that an unfair election. Following the way to protect the legitimate government of the Syria, on 30 September 2015,Russia began air strike in favor of president Bashar al-Assad.After that, Rush authority stated Russia launched air campaign at the request of the president al-Assad. For as much as the Russian government is thinking the air strike in Syria is wholeheartedly legal. In an interview with Euro news TV channel Prime Minister Dmitry Medvedevs said, "There is a legal foundation in the form of the request by president al-Assad" ${ }^{31}$ In a question of Euro news presenter Isabelle Kumar, Mr. Prime minister answered,

"we simply believe that there is currently no other legitimate authority in Syria apart from Bashar al-

Assad. He is incumbent president, whether anyone likes it or not. Taking him out of this equation

would lead to chaos. We have seen that on numerous occasions in the Middle East, countries

simply fell apart, as it happened with Libya, for example.",32

In another interview with CNBC, on 15 October 2014, the Rush prime Minister explained only Bashar al-Assad government is the key protector of the sovereignty of the Syrian people. ${ }^{33}$ So it is very obvious that from the Russian point of view, President al-Assad is the legitimate president who has adequate followers in Syria and Russia doesn't want to espy another war-torn country such as Libya, Iraq, where western powers (America and her allies) became driving power who is manipulating society, state and humanity in the name of democracy.

\subsection{Strategic Importance}

In the contemporary world, scholars and researchers of the international history are demystifying that Russia is re-emerging as a great world power and oppugning to the western world. Despite the declining of Soviet Union in 1991, Russia suffered extreme social, economic, political crisis, under the president Yeltsin leadership, Russia was trying to retake his respect nationally and internationally. Throughout the entire time of the president Vladimir Putin, It became more outspoken and apparent thought that Russia was again ascending as a great power. ${ }^{34}$ Vladimir Putin stated "Russia will remain a great power, preconditioned by the inseparable characteristics of its geo-political, economic and cultural existence. " ${ }^{35}$ From the inception of the President Vladimir Putin period, he griped multivector foreign policy 'which means as independent policy with relations and interest with many directions'. The objective of this policy is "Russia has to play the whole field, not only some of the squares, if it wants to remain a world power." ${ }^{36}$ The changing foreign policy of the Russia becomes a change in the world politics that is not unknown to the world. In such a way Russia played a pivotal role in Georgian war (2008) and for the annexation of Crimea on 18 March 2014 and also dominating in Ukraine and the Syrian crisis. Just like that Middle East is a place of the great game where super powers want to appear their power and to build up fastening relationship with strategically situated countries. Syria is one of the pivotal geostrategic countries in the Middle East which is bordered by turkey on the north, Lebanon, and Israel on the west, Iraq on the east and Jordan on the south. Henry Kissinger once said there can be no peace in the Middle East without Syria. So Russia is examining Syria as a crucial country that has been already discussed in the background.

From the President Vladimir Putin's point of view is to strengthen Russia as a twenty-first century world power. ${ }^{37}$ To such a degree if Russia is able to defeat Syrian rebellion group, Russian position in the Middle East will be more powerful. That way a new polarization could be happened by the Russian leadership.

\section{CONClusion}

Syrian civil war is continuing From 15 march 2011 to still now. No one knows when the war will be ceased. There are no fixed statistics that how many people have died from the inception to running days of the war. The observatory for human rights (SOHR) has estimated about 430 thousand people were killed since the beginning of the Syrian civil war. ${ }^{38}$ The UNHCR has assessed more than7, 600,000 Syrian people displaced and over 4,000,000 become refugees till July $2015 .{ }^{39}$ Finally, on 10 September 2016, The Russian and the USA foreign ministers were consented to cease fire in Syria. As 
follows, 48 hours ceased fire started from 12 September night. But conflicts do not come to an end and Rush fighters are continuing bombing on the opponents groups of the president al-Assad government. Randa Slim, director of the Middle East Institute, thought such peace initiative cannot ensure for the long term peace install. ${ }^{40}$ But the foremost hindrance is the empowering of al-Assad to establish full peace in Syria. The USA and the opponents groups do not recognize the authority of alAssad. Washington and the rival group leaders are states again and again for the full installation of peace, Bashar al-Assad must have to remove from the power. But president al-Assad does not agree to move from the government and also his prime ally Russia does not want this. Moscow has said again and again if Assad is removed from the government that will create another Afghanistan, Libya, and Iraq which is not acceptable. President Putin said, "It is impossible to defeat the Islamic group without cooperating with Damascus." ${ }^{, 4} \mathrm{He}$ desired other nations should follow Russia's example and give military support to Assad's government for the winning against ISIS. From the Russian vantage point, following the way again Syria will become a stable country in the Middle East.

1. Dmitry Medvedev's interview with Euro news TV channel, http://government.ru/en/news/21789/

2.Alan Wood, The Origin of the Russian Revolution(1861-1917), Third Edition, Rutledge,London,2003,pp.43-44, http://www.bbc.co.uk/schools/gcsebitesize/history/mwh/russia/firstworldwarrev1.shtml

${ }^{3}$. Robert A. Saunders, VladStrukov, Historical Dictionary of the Russian Federation, The Scarecrow Press, Inc.Lanham,2010,p.416, http://www.encyclopedia.com/topic/Union_of_Soviet_Socialist_Republics.aspx,

${ }^{4}$.AnoushiravanEhteshami, Dynamics of Change in the Persian Gulf Political Economy, War and Revolution, Routledge, New York 2013, p.17

5 . Raymond Hinnebusch, Syria: Revolution Form Above, Routledge, New York, 2001, p.137.

${ }^{6}$ Alasdair Drysdale and Raymond A. hinnebusch, Syria and the Middle East Peace Process, Council on Foreign Relation Press, New Yourk,P.2

${ }^{7}$. http://www.jewishpolicycenter.org/2009/02/28/the-syria-soviet-alliance/

${ }^{8}$.YacoovRo'I, Boris Morozov (ed.) The Soviet Union and the June 1967 Six Day War, Stanford University Press, Stanford,2008,P.79

${ }^{9} \mathrm{http}: / / \mathrm{www}$.jewishpolicycenter.org/2009/02/28/the-syria-soviet-alliance/

${ }^{10}$ TalalNIzameddin, Russia and the Middle East: Toward a new foreign policy, Hurst and Co. (Publishers), Ltd.London,1999, P.38

${ }^{11}$. Robert Owen Freedman, Soviet Policy Toward Israel Under Gorbachev, Centre for Strategic and International Studies, Washington, D.C. P.102

${ }^{12}$. Fleron, Contemporary issues in Soviet Foreign Policy, Transaction Publishers, New Burnswick,p.685.

${ }^{13}$. Ibid

${ }^{14}$. Ibid, P.690

${ }^{15}$.Andrej Kreut, Russia and the Middle East: Friend or Foe, Green Wood Publishing Group, Praeger Security International Series, London, 2007,p.29

${ }^{16}$. Vladimir Putin answered Russian journalist's questions on September 4,2015 in Vladivostok, http://en.kremlin.ru/events/president/news/50234

${ }^{17}$. Dmitry Medvedev's interview with Euro news TV channel, 14, February 2016,

Munich Germany, http://government.ru/en/news/21789/

${ }^{18}$. Polis journal vol.2, winter 2009, university of leads 2009,p.20, Bangladesh Historical Studies, vol.xxiii 2012-14, Dhaka, May 2015,p.261

${ }^{19}$. https://www.stratfor.com/weekly/20100706_caucasus_cauldron

${ }^{20}$.David R. Stone, A Military History of Russia: From Ivan the Terrible to the War in Chechnya, Prager Security International, London 2006, p.244

${ }^{21}$. Charles King, The Ghost of Freedoms A History of The Caucasus, Oxford University Press,USA, P.17 
${ }^{22}$. https://themoscowtimes.com/news/moscow-says-it-thwarted-is-terror-attacks-in-russia-51648

23 .Dmitry Medvedev interview with Time Magazine, http://government.ru/en/news/21790/

${ }^{24}$. Ibid,Dmitry Medvedev's interview with Euro news TV channel, http://government.ru/en/news/21789/

25. Dmitry Medvedev interview with Time Magazine, http://government.ru/en/news/21790/

${ }^{26}$.https://themoscowtimes.com/news/moscow-says-it-thwarted-is-terror-attacks-in-russia-51648

${ }^{27}$.Dmitry Medvedev interview with Handelsblatt, http://government.ru/en/news/21765/

${ }^{28}$. https://themoscowtimes.com/news/moscow-says-it-thwarted-is-terror-attacks-in-russia-51648

${ }^{29}$. understandingwar.org/backgrounder/isis-declares-governorate-russia's-north-caucasus-region

${ }^{30}$.Ibid

${ }^{31}$.Dmitry Medvedev interview with Euronews TV channel, http://government.ru/en/news/21789/

${ }^{32}$.Ibid

${ }^{33}$.Dmitry Medvedev interview with CNBC, http://government.ru/en/news/15235/ , http://www.cnbc.com/2014/10/15/cnbc-exclusive-transcript-russian-prime-minister-dmitry-medvedev-speakswith-cnbcs-geoff-cutmore-today.html

34. Roger E. Kanet (ed.), Russia Re-Emerging Great Power, Palgrave Macmillan, New York, 2007, p.14

${ }^{35}$.Ibid,Jackie Gower, Graham Timmins (ed.), Russia and Europe in the Twenty First Century: A Uneasy Partnership, Anthem Press, London,p.189

${ }^{36}$. Roger E. Kanet (ed.), Russia Re-Emerging Great Power, Palgrave Macmillan, New York, 2007, p.18, http://eng.globalaffairs.ru/number/Vladimir-Putins-Fourth-Vector---16048

${ }^{37}$. Roger E. Kanet (ed.), Russia Re-Emerging Great Power, Palgrave Macmillan, New York, 2007, pp.15-16,

${ }^{38}$.http://www.syriahr.com/en/?p=50612

${ }^{39}$.http://america.aljazeera.com/articles/2015/7/9/unhcr-syrian-refugees-cross-four-million-mark.html, https://en.wikipedia.org/wiki/Syrian_civil_war

${ }^{40}$.Daily Ittefaq, Dhaka, 19 September 2016

${ }^{41}$. http:www.themoscowtimes.com/news/article/assad-praises-role-as-impartial-broker-in-defeatingterrorism/531098.html

\section{AUTHOR's BIOGRAPHY}

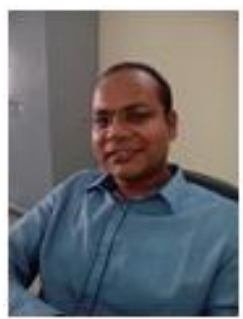

Md. Shafiqur Rahaman, lecturer of Pabna University of Science and Technology, Department of History and Bangladesh Studies, is the co-author of History of the Far-East and South-East Asia in Modern Times (In Bangla, Aparajeyo Bangla Publication, Dhaka, 2016). His research is on the US security policy in central Asia, Intellectual history of the Bengali Muslims and the political history of the South-east Asia. His particular research interests include intellectual history, history of thought, superpowers' foreign policy and contemporary international politics. 